\title{
IS TRADE GOOD FOR YOUR HEALTH?
}

\author{
Ann L. Owen and Stephen Wu
}

Hamilton College

August 2002

\begin{abstract}
We use a panel of 139 countries to examine the relationship between a country's openness to international trade and several health outcomes and find that, in general, increased openness is associated with lower rates of infant mortality and higher average life expectancies, especially in developing countries. There is some preliminary evidence suggesting that part, but not all, of the positive association between openness and health may result from more open economies receiving more development aid.
\end{abstract}

We are grateful to Anne Case, Oded Galor, Derek Jones, Jeffrey Pliskin, Jonathan Rork, Harvey Rosen and Bent Sorensen for helpful comments and suggestions.

Ann L. Owen

Department of Economics

Hamilton College

Clinton, NY 13323

315-859-4419

aowen@hamilton.edu
Stephen $\mathrm{Wu}$

Department of Economics

Hamilton College

Clinton, NY 13323

315-859-4645

swu@hamilton.edu 


\section{Introduction}

Critics of the current wave of globalization argue that increased international trade may harm the poor, especially those in developing countries. In addition, although much economic theory predicts that trade increases average incomes, it also highlights distributional consequences that may adversely affect the poor. In this paper, we evaluate the effects of trade on welfare by looking at how openness to trade influences health outcomes. Our work is particularly relevant to the concerns of trade's impact on the poor as it is likely that improvements in aggregate measures of health outcomes are concentrated among the poor. Our major finding is that increased openness is robustly associated with lower infant mortality and higher life expectancies in developing countries. In richer countries, these effects are more muted. We provide some preliminary evidence that suggests that part, but not all, of the explanation for these results is that more open economies receive more development assistance.

Our work is related to the active debate on the effects of international trade on welfare as measured by growth of per capita income. Sachs and Warner (1995) show that incomes of open economies tend to converge while those of closed economies do not. In another influential paper, Dollar (1992) finds that exchange rate distortion and exchange rate variability are negatively correlated with growth. More recently, Rodriguez and Rodrik (2001) call these findings into question by showing a lack of robustness for some results and casting doubt on the interpretations of others. ${ }^{1}$ In a related paper, Dollar and Kraay (2000) specifically examine the effects of globalization on the poor and find that the poor benefit from openness to the same extent that the entire economy benefits.

\footnotetext{
${ }^{1}$ Ben-David (1993), Edwards (1998), Lee (1993), Harrison (1996) and Wacziarg (1998) are other recent papers critiqued by Rodriguez and Rodrik (2001) that find a positive role for trade in the growth process. For a survey of earlier literature on this topic, see Edwards (1993).
} 
There also exists a substantial body of work that links economic activity to health status both at the country and the household level. At the macroeconomic level, Waldmann (1992) finds evidence for a link between income distribution and infant mortality. Pritchett and Summers (1996) show that wealthier economies have lower infant mortality rates and higher life expectancies and Bhargava et. al. (2001) show that countries with better health outcomes grow faster. ${ }^{2}$ At the household level, there is evidence that serious health events lead to large declines in household wealth (Smith 1999 and McClellan 1998). Socioeconomic status has also been linked with infant mortality (Meara 1998) and also behavioral patterns such as smoking and drinking (Marmot, Shipley and Rose 1984).

Finally, there is a large literature on the effect of trade on income inequality. Although many studies have found a minor role for trade in widening inequality, Borjas and Ramey (1994) and Karoly and Klerman (1994) argue that the impact of trade is significant (see also, Wood 1994). Most of this literature, however, focuses on increasing earnings inequality in industrialized countries, while our results suggest that the improvements in health outcomes are most dramatic in developing countries. ${ }^{3}$ Furthermore, even if trade causes greater inequality in incomes, our findings show that inequality in other measures of welfare are reduced by trade.

The effects of openness on health (holding income constant) can operate through a variety of links. Bhagwati (1998) suggests that health, particularly in developing

\footnotetext{
${ }^{2}$ Interestingly, Pritchett and Summers (1996) use different measures related to openness to trade (terms of trade, black market premium, and price level distortion) to instrument for per capita GDP in regressions explaining infant mortality and life expectancy. They obtain insignificant coefficients on the instrumented GDP in all three cases.

${ }^{3}$ See Burtless (1995), Freeman (1995), and Richardson (1995) for a more thorough discussion of the literature on earnings inequality and trade.
} 
countries, would be improved as a result of integration into the world economy as more doctors and medical technologies cross borders and patients seek care in better or lower cost facilities in other countries. Other health benefits of openness might occur through the increased trade of medical supplies and drugs, especially vaccines in developing countries, and the general flow of knowledge that might aid the design and administration of public health programs. On the other hand, health may deteriorate as a result of trade if the economic activity associated with international trade becomes more dangerous, general working conditions deteriorate, or trade facilitates the transfer of disease or unhealthy consumer goods and practices across borders. ${ }^{4}$

Our results show that the beneficial effects of trade on health outweigh any negative effects and that these effects are the results of several different linkages. While greater access to "raw materials" such as vaccines are associated with better health outcomes, there is still a role for openness in affecting health that is independent of this channel. We also find some suggestive evidence that foreign aid devoted to water resources is more likely to be awarded to open economies and that this development aid is associated with better health outcomes. Thus, at least part of the explanation for the better health performance of open economies may be the increased aid they receive. ${ }^{5}$

\footnotetext{
${ }^{4}$ For example, Richter (1980) finds evidence suggesting that occupational accidents and sick days would be reduced if Austria were closed to international trade.

${ }^{5}$ Some researchers find that aid is not correlated with macroeconomic policies, but with the donor country's self-interest (Boone 1996 and Burnside and Dollar 2000). Alesina and Dollar (2000) show that foreign aid is determined as much by political and strategic considerations, as by the economic needs and policy performance of the recipients. Our result that openness to imports is positively related to aid received is consistent with both the donor self-interest finding (e.g., self-interested donors reward countries that are open to their exports) as well as one in which altruistic donors reward certain macroeconomic policies.
} 
The remainder of the paper is organized as follows. Section 2 explains the methodology and introduces the data. Section 3 presents the empirical results and discusses reasons for the relationship and Section 4 concludes.

\section{Methodology and Data}

To explore the relationship between health and trade, we adopt the following specification:

$$
\begin{aligned}
& h_{i, t}=\beta_{0}+\beta_{1} \ln \left(G D P_{i, t-1}\right)+\beta_{2} \ln \left(\text { open }_{i, t-1}\right)+\beta_{3} \ln \left(\text { GDP }_{i, t-1}\right) * \ln \left(\text { open }_{i, t-1}\right) \\
& +\beta_{4} X+\alpha_{i}+\lambda_{\mathrm{t}}+\varepsilon_{i, t}
\end{aligned}
$$

where $i$ denotes a country subscript and $t$ denotes time. In Equation $1, h$ is one of four different measures of health outcomes (infant mortality, life expectancy of females, life expectancy of males, overall average life expectancy). GDP is measured as real GDP per capita in 1985 U.S. dollars, open is defined as (exports+imports)/GDP and $X$ is a vector of additional control variables that may be associated with health outcomes. $\alpha$ is a country specific effect, $\lambda$ is a time specific effect and $\varepsilon$ is a mean zero normal disturbance term. $^{6}$

We use a fixed-effects approach to estimate Equation 1 with panel data from 139 countries over the period from 1960 to $1995 .^{7}$ Because changes in health outcomes are likely to evolve over a number of years, we use observations at five-year intervals (1965,

\footnotetext{
${ }^{6}$ The primary measure of openness in our analysis is the volume of trade, as opposed to a direct measure of policy stance. Thus, the policy prescription of our initial results is to implement policies to increase the volume of trade, a slightly stronger policy action than simply being open to trade. (See also Rodriguez and Rodrik, 2001 for a discussion of this issue.) However, in later results we use a more direct measure of policy - the black market premium - as an alternative measure of openness.

${ }^{7}$ We include all countries for which data is available except for former planned economies.
} 
1970, 1975, 1980, 1985, 1990, and 1995). ${ }^{8}$ Equation 1 incorporates lagged values of openness because any causal relationship between openness and changes in health outcomes is not likely to be contemporaneous. ${ }^{9}$ Finally, by interacting per capita GDP and openness, we allow for the effect of openness to vary with the country's income and do not restrict the effect of openness to be the same in developing and developed economies.

Although in our sensitivity analysis we vary the control variables in X, our initial results use gross secondary school enrollment rates and population growth rates. We include school enrollment rates because more educated populations may have better knowledge about healthy practices and secondary school enrollment rates may also be a more general proxy for human capital investment policies. Finally, we include population growth because of a potential link between this and life expectancy or infant mortality. ${ }^{10}$

Our data are derived from two sources. Per capita GDP, openness and population are obtained from the Penn World Tables Mark 5.6, while the four measures of health outcomes and secondary school enrollment rates are taken from the World Bank's 2001 World Development Indicators. Life expectancy is measured in years and infant mortality is reported per 1,000 live births.

\footnotetext{
${ }^{8}$ A Hausman test confirms our choice of fixed vs. random effects with p-values less than .05 for each of the estimations in our main specification. All of the results we report are robust to using ten-year intervals, although this choice reduces our sample size considerably.

${ }^{9}$ Nonetheless, our results are also robust to using contemporaneous values of our independent variables.

${ }^{10}$ Ceteris paribus, longer life expectancies and lower infant mortality rates should lead to higher population growth rates. The correlation between health outcomes and population growth may be negative, however, if higher rates of population growth are associated with lower access to medical care. While World Development Indicators do include some recent data on access to medical services, the data are not available in earlier years and cannot be used in our panel estimation. In section 3.4, we utilize some additional variables that measure access to medical care more directly in some cross-section estimations.
} 


\section{Results}

\subsection{Descriptive Statistics}

Table 1 presents summary statistics of the relevant variables, including real per capita GDP, population growth, secondary schooling enrollment rates, certain health indicators, and openness. The standard deviations of the life expectancy and infant mortality variables indicate that there is great variation between the health outcomes of the various countries. For example, Sweden has an infant mortality rate of only 3.7 per 1,000 births in 1995 while the analogous number for Sierra Leone is nearly 180 per 1,000 births. The discrepancy between the highest and lowest life expectancies is equally startling with New Zealand's average life expectancy being over 79 years and Sierra Leone's being only 36 . There is also a large amount of variance in openness to trade. In 1990, the sum of Singapore's imports and exports is almost 4 times its GDP, while in the same year, Brazil's ratio is less than one-eighth.

\subsection{Openness and Health Outcomes}

Estimation results for equation 1 are shown in Table 2. The first column for each health outcome includes only the log of per capita GDP, the log of openness, an interaction term, and country and year effects. In the three equations with measures of life expectancy used as the dependent variable, the positive coefficients on the GDP variables indicate that richer countries have better health outcomes. While the coefficient on openness is positive, the interaction term between the two has a negative sign, implying that the positive effect of openness on health is strongest for poorer countries. ${ }^{11}$

\footnotetext{
${ }^{11}$ While some may interpret this result as being due to the fact that the poorest countries start out with the worst health outcomes, using the logarithm of health outcomes yields the same conclusions for average life
} 
This interaction term is statistically significant at the $10 \%$ level in all three life expectancy equations.

For infant mortality, all of the coefficients are of the opposite sign to the life expectancy equations, which is expected given the fact that lower numbers signify a better health outcome. Once again, the interaction term is statistically significant and suggests that the decrease in infant mortality rates due to increased openness is strongest for poorer countries. Countries that become richer and more open have lower infant mortality rates, but the benefit of openness is strongest for poorer countries. ${ }^{12}$

The magnitude of the impact of openness is meaningful. The results imply that a one standard deviation increase in the log of openness for a country that is in the lowest quintile of real GDP is associated with a drop of approximately 7 infant deaths per 1,000 (a reduction in the average rate of infant mortality of about $8 \%$ ). Increases in female life expectancy in the poorest countries are also notable, with a one standard deviation increase in the log of openness producing an increase in female life expectancy of 1.39 years (2.3\% of the average female life expectancy in the full sample). A similar calculation yields an increase in male life expectancy of 0.83 years, a slightly smaller, but still significant impact of openness.

expectancies, though not for infant mortality. However, we report the results using the levels of health outcomes to focus on the absolute changes in outcomes, instead of relative ones. In fact, one reason that health outcomes in poorer countries may catch up with those in more developed ones is that poorer countries that interact with the rest of the world may be able to adopt health practices and technologies used in other countries.

${ }^{12}$ A literal interpretation of the coefficients presented would imply that in developed economies more openness may actually worsen health outcomes (about 60 percent of our sample is above this break-even point). However, when we split the sample at the break point implied by these coefficients and then reestimate equation 1 using only the richer countries, we again find that openness is positively associated with health, but the effect diminishes as GDP per capita increases even within this sub-sample. (We do not find a statistically significant interaction term in the developing country sample.) In other words, increased openness is not necessarily associated with decreased health in developed economies, only that the effect is weaker for richer countries. 
It is interesting to note that the largest impact of openness (in percentage terms) is for infant mortality. A possible explanation is that when trade is more free flowing, the improved access to resources in developing countries is more heavily concentrated in immunizations or pre-and post-natal care. This hypothesis is also supported by the fact that the magnitude of the effect of openness on female life expectancy is slightly larger than for the male life expectancy equation. We will examine some of these issues in Section 3.4. Prior to taking up this issue, however, we explore the robustness of our results.

One possibility is that changes in some other demographic variable may be driving this result. Perhaps as a country improves its educational system, its health outcomes improve, and it happens to become more open to international trade in the process. To address this issue, the second column for each health outcome equation includes population growth and secondary schooling enrollment rates as covariates in the regression. ${ }^{13}$ As expected, the coefficient on secondary schooling shows that increased education is associated with better health outcomes, but the coefficient on population growth is statistically insignificant in explaining any of the four measures of health outcomes. Importantly, the coefficients on openness to trade continue to be of the same sign as in the basic specifications, and all are statistically significant at the $10 \%$ level. Even after controlling for the differences in these demographic characteristics between

\footnotetext{
${ }^{13}$ One might also wonder about a causal relationship between trade and population growth. Increases in all four of our health outcome measures would tend to increase population growth rates, holding all else constant. However, when we estimate the impact of trade on fertility using the logs of per capita GDP, openness, secondary schooling enrollment, and an interaction between per capita GDP and openness, we find some weak evidence suggesting that increased openness is associated with lower fertility rates and that this effect is particularly strong in developing countries. Thus, for the time period and the intervals we examine, increased trade may hasten the demographic transition in developing countries. In a related paper, Galor and Mountford (2001) examine the relationship between trade and population growth over the very long run and argue that increased trade in less industrialized countries would lead to higher rates of population growth through a Malthusian mechanism.
} 
countries and across time, a country's openness to foreign trade continues to be an important determinant of health outcomes. More open countries have higher average life expectancies and lower rates of infant mortality, and the effects are strongest for developing countries. It is important to note that in using a fixed effects specification, the potential for omitted variables driving the results is limited. Country specific characteristics that are fixed over time, such as geography and climate, will not bias the results obtained in the analysis. In the next section, however, we do investigate the sensitivity of our results to other possible omitted variables.

\subsection{Sensitivity Analysis}

\subsubsection{Alternative Measures of Openness}

To test the robustness of the results, we repeat the previous analysis using three other measures of openness: imports as a proportion of GDP, exports as a proportion of GDP and the black market premium. The black market premium indicates the extent of distortion in the market for foreign currency. The basis for using this measure of openness is that higher black market premiums imply more trade barriers due to foreign exchange restrictions. The black market premium may also signal other macroeconomic imbalances or an inefficient policy environment in general which could also be associated with lower health outcomes. Thus, it is a more direct measure of trade policy, but it may also be correlated with other macroeconomic policies that could impact health outcomes.

The results using these other openness measures are shown in Table 3. The results using the exports/GDP as a measure of openness appear in the top panel, results using imports/GDP appear in the middle panel, and results using the black market premium appear in the bottom panel of the table. These results strongly confirm the 
initial findings. ${ }^{14}$ Whether we use a more direct measure of trade policy (black market premium) or an alternative measure of trade volume (exports or imports), we find that increased openness to trade improves all four health outcomes and that the effect is particularly strong in developing countries.

The magnitudes of the effects identified with the alternative measures of openness are similar to those reported earlier. For example, a one standard deviation decrease in the log of the black market premium is associated with a drop in the infant mortality rate of 3 per 1,000 and an increase in female life expectancy of one-half year in the subsequent five years.

\subsubsection{Sample Selection and Additional Control Variables}

In order to demonstrate that our main findings regarding the relationship between openness and health are robust, we modify our sample and specification in several different ways. ${ }^{15}$ We discuss these further robustness checks in this section.

Although our sample size is relatively large for a cross-country data set, it may be sensitive to the inclusion of some outliers. Some countries experienced extremely large changes in openness and/or health outcomes during the observed time period. To ensure that these countries were not overly influential in determining our results, we also estimated equation 1 after dropping countries with the largest changes (positive or negative) in openness and countries with extremely large changes in any of the health indicators. We found the results to be robust to these changes in the sample. It is also possible that oil-exporting countries whose exports are primarily determined by natural resource extraction may behave differently than countries that mostly trade other raw

\footnotetext{
${ }^{14}$ Note that decreases in the black market premium signal increases in openness.

${ }^{15}$ Detailed results for any of the exercises described in the text are available from the authors upon request.
} 
materials and manufactured goods and services. However, we also confirmed that our results are robust to eliminating the OPEC countries from our sample.

Some have suggested that income inequality may be related to health outcomes through the link between socioeconomic status and health at the household level. ${ }^{16}$ As noted in the introduction, there is reason to believe that income inequality may be related to international trade and we would be concerned if including a measure of income inequality affected our results. While a large panel of income inequality data is not available, we were able to construct a smaller panel (124 observations) to re-estimate equation 1 , adding the Gini coefficient to the control variables in $\mathrm{X}^{17}$ We do not find a significant coefficient on income inequality and the signs and significance of openness and its interaction with GDP are preserved. ${ }^{18}$

Others have found that the level of female education (even after controlling for the overall level of education) may be related to infant mortality as better educated women will have better prenatal care and also be better prepared to care for an infant. ${ }^{19}$ However, we find that including female secondary school enrollment rates in the infant mortality estimation does not yield a statistically significant coefficient and does not affect our conclusions about the effects of openness, even though adding this variable gives us a slightly smaller sample size.

\footnotetext{
${ }^{16}$ See for example, Flegg (1982) or Rogers (1979).

${ }^{17}$ Gini coefficients are obtained from Deininger and Squire (1996). To construct this panel, we follow Forbes (2000) and select income inequality observations for each year if there is an observation within the five previous years.

${ }^{18}$ Ideally, one would want to explore the relationship between inequality, trade, and health outcomes more thoroughly with other measures of income distribution that focus on the welfare of the poorest people in the country (e.g., the poverty headcount). It is possible that the improvements in health outcomes at the country level are heavily influenced by improvements among the poor. Unfortunately, sufficient data is not available to explore this mechanism empirically.

${ }^{19}$ See, for example, Mellington and Cameron (1999) or Subbarao and Raney (1995).
} 
Finally, the relationship we find between openness to trade and health outcomes may be spurious if lack of openness is highly correlated with an unstable political environment and political instability is the cause of poor health outcomes. To confirm that our results are not driven by this correlation we also included a dummy variable indicating if the country had been in a civil war in the previous five years. ${ }^{20}$ However, our conclusions are not sensitive to the inclusion of this variable either.

\subsection{Mechanisms for Openness Effects}

While we have presented fairly strong evidence that, holding income constant, openness and health outcomes are related, we have not demonstrated the reasons for such a link. There are many potential channels through which openness may affect health, particularly for poorer countries. Openness to trade may be associated with the type of political regime within a country, which could influence the development of health care systems and access to health care for the poor. Lower trade barriers and more open trade may also allow developing countries to gain access to medical resources such as prescription drugs and vaccines. Another possibility is that the receipt of development aid, which could improve health outcomes, may be correlated with a country's economic policies such as its openness to foreign trade. Or perhaps patients in open economies with less developed health care systems may cross international boundaries to receive treatment from more trained physicians and better equipped facilities. Finally, there may be a large inflow of health knowledge that is transmitted more easily when countries do not restrict foreign trade.

\footnotetext{
${ }^{20} \mathrm{We}$ use data from Sambanis (2000) to construct this dummy variable.
} 
In this section, we discuss the evidence for several of these channels. While we are unable to provide evidence on links between openness, health outcomes and the number of patients or the knowledge that crosses borders as countries open up to trade, we are able to investigate the first three channels mentioned above: openness and the political regime, importation of medical resources, and openness and development aid.

We begin by addressing the issue of political climate within a country. If openness to trade is associated with political environments and those political environments influence health outcomes, the effects of increased openness on health may be attributed to changes in the political environment. To test this idea, we use the Polity data series, constructed by the Center for International Development and Conflict Management, which contains variables describing regime and authority characteristics for many of the countries in our data over time. ${ }^{21}$ The Polity data contains eight different indices of democracy/autarky of regimes and we augment the panel estimations in Table 2 with each of these indices. None of the health outcome measures are significantly related to the political variables and we do not report the results here. Furthermore, including these variables in the main regressions does not change the magnitude or significance of the main results. Thus, we find no evidence that the positive correlation between openness and health outcomes can be attributed to changes in the political environment.

We next explore the possibility that developing countries that become more open are able to import more medicine from foreign countries, which in turn leads to better health outcomes. In cross-sectional analysis, we are able to document the fairly obvious

\footnotetext{
${ }^{21}$ The data and a more thorough description of all the variables in it can be obtained at http://www.cidem.umd.edu/inscr/polity/.
} 
result that greater availability of vaccines improves health outcomes by confirming that higher rates of measles and DPT immunizations lead to lower infant mortality rates and higher life expectancies. ${ }^{22}$ A logical next step is to determine if the link between openness and health outcomes is a result of the effect of imports of pharmaceutical products on health.

To test this channel, we obtained United Nations trade data that details both the dollar value and the quantity (weight) of imports of medicinal products. ${ }^{23}$ We use this data to create two new variables, the dollar value of medicinal imports/dollar value of GDP and the quantity of medicinal imports per person. (The dollar value of GDP is obtained from the World Bank's Development Indicators.) We included these two measures of imports of medical resources in the main panel regressions in Table 2 both with and without the more general measure of openness. We find no evidence that increases in these specific types of imports lead to better health outcomes and we do not report the detailed results here. In fact, there is some evidence of reverse causality in this situation - in a few specifications we found evidence that countries tend to import more pharmaceutical drugs when health outcomes are bad. Therefore, while our cross-sectional evidence supports the idea that usage of medical resources leads to better health outcomes, we find no evidence that the importation of these resources is a critical link in explaining the positive correlation between openness and improved health in developing countries.

\footnotetext{
${ }^{22}$ Unfortunately, there is not enough data on immunization rates to conduct a panel analysis. However, when including the immunization variables in a cross-sectional specification similar to the panel estimation in Table 2, the original results for openness continue to hold—countries that are more open to trade have better health outcomes, and the benefit of openness is strongest for the poorest countries. In addition, the magnitudes of these effects are almost identical with and without controls for immunization rates.

${ }^{23}$ We used SITC code 541, Medicinal Products. This category includes drugs such as antibiotics and vaccines as well as medical supplies (e.g., bandages).
} 
Another possible reason for the association between international trade and health outcomes is that foreign aid, some of which may be used to improve public health, may be linked to a country's economic policies, including its openness to trade. To test this hypothesis, we look at the relationship between several different measures of foreign aid and health outcomes. We look at both general overall aid as well as specific types of aid that might be particularly important in influencing health outcomes. The types of development aid we examine included total development aid, technical cooperation, food aid, water supply and sanitation aid, emergency assistance, program assistance, and social infrastructure and services aid (all are measured per capita). ${ }^{24}$

As before, we add each of these measures of aid to the main specification in Table 2 to determine if they 1) influence health outcomes, and 2) influence the coefficient on openness and its interaction with per capita GDP. While most of the different kinds of aid are not consistent predictors of health outcomes, increases in per capita water resources aid are associated with lower infant mortality and higher life expectancies. ${ }^{25}$ The results for the regressions including water aid as an explanatory variable are reported in Table 4.

Aid data is only available for a subset of our original sample, so the resulting sample is significantly smaller than the samples used in previous tables. Thus, we present results for specifications with and without the control for water aid in columns 1 and 2, respectively, for the same sample of observations (only those with non-missing aid data).

\footnotetext{
${ }^{24}$ The development aid data is from the OECD's International Development Statistics data base. Total development aid, technical cooperation, and food aid include both bilateral and multilateral aid. Water supply and sanitation, emergency assistance, program assistance, and social infrastructure and services aid includes only the aid given by the 22 countries of the OECD's Development Assistance Committee.

${ }^{25}$ Our finding that only a certain kind of development aid is associated with improved health outcomes is consistent with that of Boone (1996) who finds that total development aid/GDP is not significantly related to improvements in several human development indicators.
} 
The coefficients on water resources aid are significant for all four health outcome measures. However, the coefficients on GDP, openness and the interaction all continue to be significant, though slightly smaller in magnitude. The implied marginal effects of openness are somewhat reduced between columns 1 and 2. For example, a one standard deviation increase in openness for a country in the lowest quintile of GDP increases overall life expectancy by 1.08 years when no control for water aid is included, and by 0.97 years when this measure is added as an explanatory variable.

While water resources aid explains at least part of the reason that openness is linked to health outcomes, the effects are still modest. Nonetheless, it suggests that one of the mechanisms linking openness and better health outcomes might be the receipt of foreign aid. Clearly, however, there is much of the relationship between openness and health that is not explained by increased development assistance.

Of course, in order for some of the link between openness and health to be explained by the receipt of development aid, there must be a link between openness and the amount of aid received. To further explore this issue, we examine the relationship between per capita water resources aid and several measures of openness in Table 5. We predict water aid per capita using openness, GDP, and controls for secondary schooling and population growth. Because we only have data for countries that receive a positive amount of aid, this estimation predicts the amount of aid conditional on the receipt of aid. The results indicate that water aid is positively correlated with imports/GDP, (imports+exports)/GDP, and exports/GDP, and negatively related with the black market 
premium, though the coefficient for the last measure is not statistically significant at the $10 \%$ level. $^{26}$

There are two possible interpretations of these results. One is that the donor policies of giving aid depend on a country's economic policies and trade environment. Another is that a country may become more open to trade as a result of the increased foreign aid. The fact that the black market premium, an easily observable indicator of policy distortion, is not significant in these equations but openness to imports is significant casts doubt on the proposition that donor countries are altruistically rewarding sound macroeconomic policies, but, rather, may be rewarding countries that are open to the donor country's exports. ${ }^{27}$

In summary, we have found some suggestive evidence that openness to trade may be linked to better health outcomes because more open countries receive more water resources aid, though our results indicate that this explanation is only a partial one. It seems intuitive that cleaner water would greatly benefit a country's health outcomes, particular for lesser developed countries where water quality is likely to be an issue. Still, the effect of openness remains even after accounting for possible changes in pure water supplies. We conclude that while this type of foreign aid may be a factor in explaining our results, other factors also play a role.

\footnotetext{
${ }^{26}$ In a related finding, Barro and Lee (2002) find that IMF lending is sensitive to bilateral trading volumes with major shareholding countries of the IMF.

${ }^{27}$ In a more thorough analysis of bilateral and multilateral aid, Alesina and Dollar (2000) do find support for the idea that much bilateral aid is given out to further the donor country's interests.
} 


\section{Summary}

This paper has shown that increased trade is associated with improved health outcomes, in terms of increased life expectancies and lower infant mortality, but these gains vary by country. In particular, these benefits are enjoyed primarily by poorer countries, while the benefits to more developed nations are much smaller, or even nonexistent. These findings challenge the notion that increased openness is harmful to the poor. In fact, we show that trade may actually decrease international health disparities since the gains are primarily enjoyed by poorer countries.

The mechanisms through which openness and health are related are less clear. We are able to attribute a small part of the correlation to increases in development aid being associated with increases in openness. We found no evidence that this mechanism can be explained by an association between increased openness and changes in political regimes or by the importation of medical resources. Some of the unexplained correlation may be due to mobility of doctors and patients across borders or perhaps, more generally, to the flow of knowledge that may accompany increased openness. Future research should focus on the specific channels linking openness and health so that policy makers can better understand this relationship. 


\section{References}

Alesina, Alberto and David Dollar, 2000, "Who Gives Foreign Aid to Whom and Why?" Journal of Economic Growth 5(1): 33-63.

Barro, Robert J. and Jong-Wha Lee, 2002, "IMF Programs: Who is Chosen and What Are the Effects?", NBER Working Paper No. 8951.

Ben-David, D., 1993, "Equalizing Exchange: Trade Liberalization and Income Convergence," Quarterly Journal of Economics, 108(3): 653-679.

Bhagwati, Jagdish, 1998, A Stream of Windows: Unsettling Reflections on Trade, Immigration, and Democracy (Cambridge: The MIT Press).

Bhargava, Alok, Dean Jamison, Lawrence Lau, and Christopher Murray, 2001, "Modeling the Effects of Health on Economic Growth," Journal of Health Economics, 20(3): 423-440.

Boone, Peter, 1996, "Politics and the Effectiveness of Foreign Aid," European Economic Review 40(2): 289-329.

Borjas, George and Valerie Ramey, 1994, "The Relationship Between Wage Inequality and International Trade" in The Changing Distribution of Income in an Open U.S. Economy, Bergstrand, et. al., eds., 217-242.

Burnside, Craig and David Dollar, 2000, "Aid, Policies, and Growth," American Economic Review 90(4): 847-868.

Burtless, Gary, 1995, "International Trade and the Rise in Earnings Inequality," Journal of Economic Literature, 33(2): 800-816.

Deininger, Klaus and Len Squire, 1996, "A New Data Set Measuring Income Inequality,” World Bank Economic Review 10(3): 565-591.

Dollar, David, 1992, "Outward-Oriented Developing Economies Really Do Grow More Rapidly: Evidence from 95 LDCs, 1976-1985," Economic Development and Cultural Change 40(3): 523-544.

Dollar, David and Aart Kraay, 2000, "Growth is Good for the Poor," mimeo, World Bank.

Edwards, Sebastian, 1993, "Openness, Trade Liberalization, and Growth in Developing Countries," Journal of Economic Literature 31(3):1358-1393. 
Edwards, Sebastian, 1998, “Openness, Productivity, and Growth: What Do We Really Know?” Economic Journal, 108(447): 383-398.

Flegg, A., 1982, "Inequality of Income, Illiteracy, and Medical Care as Determinants of Infant Mortality in Developing Countries," Population Studies, 36: 441-58.

Forbes, Kristin J., 2000, "A Reassessment of the Relationship Between Inequality and Growth," American Economic Review 90(4): 869-887.

Frankel, Jeffrey and David Romer, 1999, “Does Trade Cause Growth?” American Economic Review 89(3): 379-399.

Freeman, Richard B., 1995, “Are Your Wages Set in Beijing?”, Journal of Economic Perspectives 9(3): 15-32.

Galor, Oded and Andrew Mountford, 2001, "Why Are a Third of People Indian and Chinese? Trade, Industrialization and Demographic Transition," mimeo, Brown University.

Hamilton, L.C., 1991, "How Robust is Robust Regression?" Stata Technical Bulletin, 2: 21-26.

Harrison, Ann, 1996, "Openness and Growth: A Time-Series, Cross-Country Analysis for Developing Countries," Journal of Development Economics 48: 419-447.

Karoly, Lynn and Jacob Klerman, 1994, "Using Regional Data to Reexamine the Contribution of Demographic and Sectoral Changes to Increasing U.S. Wage Inequality," in The Changing Distribution of Income in an Open U.S. Economy, Bergstrand, et. al., eds. 183-216.

Lee, Jong-Wha,1993, "International Trade, Distortions, and Long-Run Economic Growth.” International Monetary Fund Staff Papers 40(2): 299-328.

Marmot, Michael G., Martin J. Shipley and Geoffrey Rose (1984), "Inequalities in Death: Specific Explanations of a General Pattern?” Lancet 1(8384): 1003-1006.

McClellan, Mark (1998), "Health Events, Health Insurance, and Labor Supply: Evidence from the Health and Retirement Study," in David A. Wise, ed., Frontiers in the Economics of Aging (University of Chicago Press, Chicago): 301-352.

Meara, Ellen (1998), "Why is Health Related to Socioeconomic Status?” mimeo, Harvard University.

Mellington, Nicole and Lisa Cameron (1999), "Female Education and Child Mortality Indonesia," Bulletin of Indonesian Economic Studies 35(3): 115-144. 
Pritchett, Lant and Lawrence H. Summers, 1996, "Wealthier is Healthier," Journal of Human Resources, 31(4): 841-868.

Richardson, J. David, "Income Inequality and Trade: How to Think, What to Conclude," Journal of Economic Perspectives 9(3): 33-55.

Richter, Josef, 1980, "Health Effects of International Trade: The Case of Austria," European Economic Review 14(3): 341-352.

Rodriguez, Francisco and Dani Rodrik, 2001, "Trade Policy and Economic Growth: A Skeptic's Guide to the Cross-National Evidence," NBER Macroeconomics Annual 2000, (Cambridge: MIT Press).

Rogers, G., 1979, "Income Inequality as Determinants of Mortality: An International Cross Sectional Analysis," Population Studies, 33: 343-52.

Sachs, Jeffrey and Andrew Warner, 1995, "Economic Reform and the process of global integration," Brookings Papers on Economic Activity 1995(1): 1-118.

Sambanis, Nicholas, 2000, "Partition As a Solution to Ethnic War: A Critique of the Theoretical Literature," World Politics, 52, 437-83.

Smith, James P., 1999, "Healthy Bodies and Thick Wallets: The Dual Relation Between Health and Economic Status," Journal of Economic Perspectives 13(2): 145166.

Subbarao, K. and Laura Raney, 1995, "Social Gains From Female Education: A Cross-National Study," Economic Development and Cultural Change 44(1):105-28.

Wacziarg, R., 1998, "Measuring the Dynamic Gains from Trade.” World Bank Working Paper 2001.

Waldman, Robert J., 1992, “Income Distribution and Infant Mortality," Quarterly Journal of Economics 107(4): 1283-1302.

Wood, Adrian, 1994, North-South Trade, Employment, and Inequality: Changing Fortunes in a Skill-Driven World (Oxford: Clarendon Press).

World Bank, 2001 Development Indicators. 
Table 1: Summary Statistics

\begin{tabular}{lcc}
\hline Variable & Mean & Standard Deviation \\
\hline Real Per Capita GDP (1985 dollars) & 3771.63 & 4119.98 \\
Population Growth & 0.02 & 0.01 \\
Secondary Schooling Enrollment Rates (\%) & 37.12 & 29.88 \\
Male Life Expectancy & 56.22 & 11.70 \\
Female Life Expectancy & 60.09 & 13.10 \\
Average Life Expectancy & 58.10 & 12.30 \\
Infant Mortality (per 1,000 births) & 81.78 & 55.83 \\
& & \\
[(Exports + Imports)/GDP] ${ }^{*} 100$ & 67.11 & 45.44 \\
\end{tabular}

Notes: Data is taken from the World Bank Development Indicators and the Penn World Tables, Mark 5.6 Observations are taken for 139 countries representing the years 1960-1990 at five-year intervals. 
Table 2: Openness and Health Outcomes

Fixed Effects Models

\begin{tabular}{|c|c|c|c|c|c|c|c|c|}
\hline \multirow[b]{3}{*}{ Explanatory Variable } & \multicolumn{6}{|c|}{ Dependent Variable } & & \\
\hline & \multicolumn{2}{|c|}{ Life Exp (Male) } & \multicolumn{2}{|c|}{ Life Exp (Female) } & \multicolumn{2}{|c|}{ Life Exp (Total) } & \multicolumn{2}{|c|}{ Infant Mortality } \\
\hline & $(1)$ & $(2)$ & $(1)$ & (2) & (1) & $(2)$ & (1) & $(2)$ \\
\hline Ln(Per Capita GDP) & $\begin{array}{c}\mathbf{5 . 5 2 3} \\
(1.154)\end{array}$ & $\begin{array}{c}\mathbf{4 . 4 9 3} \\
(1.178)\end{array}$ & $\begin{array}{c}\mathbf{5 . 6 1 1} \\
(2.106)\end{array}$ & $\begin{array}{c}\mathbf{4 . 7 7 3} \\
(2.267)\end{array}$ & $\begin{array}{c}\mathbf{4 . 6 1 2} \\
(1.518)\end{array}$ & $\begin{array}{c}\mathbf{4 . 2 6 7} \\
(1.437)\end{array}$ & $\begin{array}{c}-41.927 \\
(6.620)\end{array}$ & $\begin{array}{r}-35.419 \\
(6.730)\end{array}$ \\
\hline Ln(Openness) & $\begin{array}{c}8.658 \\
(1.790)\end{array}$ & $\begin{array}{c}6.387 \\
(1.861)\end{array}$ & $\begin{array}{c}9.795 \\
(3.267)\end{array}$ & $\begin{array}{c}8.344 \\
(3.580)\end{array}$ & $\begin{array}{c}7.312 \\
(2.399)\end{array}$ & $\begin{array}{c}5.946 \\
(2.162)\end{array}$ & $\begin{array}{l}-81.745 \\
(10.275)\end{array}$ & $\begin{array}{l}-67.721 \\
(10.636)\end{array}$ \\
\hline Ln(Per Capita GDP)^Ln(Openness) & $\begin{array}{l}-1.101 \\
(0.246)\end{array}$ & $\begin{array}{l}-0.787 \\
(0.255)\end{array}$ & $\begin{array}{l}-1.142 \\
(0.449)\end{array}$ & $\begin{array}{l}-0.920 \\
(0.490)\end{array}$ & $\begin{array}{l}-0.848 \\
(0.328)\end{array}$ & $\begin{array}{l}-0.714 \\
(0.303)\end{array}$ & $\begin{array}{c}10.645 \\
(1.411)\end{array}$ & $\begin{array}{c}8.762 \\
(1.455)\end{array}$ \\
\hline Ln(Population Growth) & & $\begin{array}{c}0.138 \\
(0.169)\end{array}$ & $\ldots$ & $\begin{array}{c}0.251 \\
(0.325)\end{array}$ & $\begin{array}{c}0.191 \\
(0.218)\end{array}$ & $\begin{array}{c}0.169 \\
(0.193)\end{array}$ & $\ldots$ & $\begin{array}{c}0.553 \\
(0.964)\end{array}$ \\
\hline Ln(Sec. Schooling Enrollment) & & $\begin{array}{c}1.236 \\
(0.252)\end{array}$ & $\cdots$ & $\begin{array}{c}0.960 \\
(0.486)\end{array}$ & $\begin{array}{c}1.100 \\
(0.325)\end{array}$ & $\begin{array}{c}0.973 \\
(0.287)\end{array}$ & $\cdots$ & $\begin{array}{r}-11.345 \\
(1.445)\end{array}$ \\
\hline $\mathrm{N}$ & 741 & 673 & 742 & 674 & 673 & 752 & 672 & 750 \\
\hline
\end{tabular}

Notes: Coefficients significant at the $10 \%$ level or better are in bold. Per capita GDP is measured in 1985 dollars. Infant mortality is measured per 1,000 births. Openness is defined as [(imports+exports)/GDP] ${ }^{\star} 100$. Measures for per capita GDP, openness and secondary schooling are 5-year lagged values. All regressions include country and year-fixed effects. Standard errors are in parentheses. 
Table 3: Alternative Measures of Openness and Health Outcomes

Fixed Effects Models

\begin{tabular}{|c|c|c|c|c|}
\hline \multirow[b]{3}{*}{ Explanatory Variable } & \multicolumn{4}{|c|}{ Dependent Variable } \\
\hline & Life Exp (Male) & Life Exp (Female) & Life Exp (Total) & Infant Mortality \\
\hline & & & & \\
\hline \multicolumn{5}{|l|}{ Openness $=(\text { Exports } / G D P)^{*} 100$} \\
\hline \multirow[t]{2}{*}{ Ln(Per Capita GDP) } & 3.779 & 3.957 & 3.856 & -26.802 \\
\hline & $(0.901)$ & $(1.740)$ & $(1.162)$ & $(5.149)$ \\
\hline \multirow[t]{2}{*}{ Ln(Openness) } & 6.557 & 8.493 & 7.480 & -65.936 \\
\hline & $(1.688)$ & $(3.258)$ & $(2.177)$ & $(9.647)$ \\
\hline \multirow[t]{2}{*}{ Ln(Per Capita GDP)*Ln(Openness) } & -0.799 & -0.947 & -0.868 & 8.511 \\
\hline & $(0.231)$ & $(0.445)$ & $(0.297)$ & $(1.317)$ \\
\hline \multirow[t]{2}{*}{ Ln(Population Growth) } & 0.159 & 0.282 & 0.217 & 0.395 \\
\hline & $(0.168)$ & $(0.325)$ & $(0.217)$ & $(0.959)$ \\
\hline \multirow[t]{2}{*}{ Ln(Sec. Schooling Enrollment) } & 1.262 & 1.007 & 1.137 & -11.634 \\
\hline & $(0.250)$ & $(0.483)$ & $(0.322)$ & $(1.429)$ \\
\hline $\mathrm{N}$ & 674 & 673 & 673 & 672 \\
\hline \multicolumn{5}{|l|}{ Openness $=(\text { Imports/GDP })^{*} 100$} \\
\hline \multirow[t]{2}{*}{ Ln(Per Capita GDP) } & 4.300 & 3.885 & 4.068 & -27.681 \\
\hline & $(1.976)$ & $(1.028)$ & $(1.326)$ & $(5.890)$ \\
\hline \multirow[t]{2}{*}{ Ln(Openness) } & 7.736 & 5.778 & 6.698 & -61.530 \\
\hline & (3.582) & $(1.865)$ & $(2.404)$ & $(10.681)$ \\
\hline \multirow[t]{2}{*}{ Ln(Per Capita GDP)Ln(Openness) } & -0.886 & -0.727 & -0.800 & 7.979 \\
\hline & $(0.488)$ & $(0.254)$ & $(0.327)$ & $(1.454)$ \\
\hline \multirow[t]{2}{*}{ Ln(Population Growth) } & 0.224 & 0.125 & 0.172 & 0.646 \\
\hline & $(0.326)$ & $(0.169)$ & $(0.218)$ & $(0.971)$ \\
\hline \multirow[t]{2}{*}{ Ln(Sec. Schooling Enrollment) } & 0.941 & 1.229 & 1.088 & -11.266 \\
\hline & $(0.489)$ & $(0.254)$ & $(0.327)$ & $(1.461)$ \\
\hline $\mathrm{N}$ & 674 & 673 & 673 & 672 \\
\hline \multicolumn{5}{|l|}{ Openness=Black Market Premium } \\
\hline \multirow[t]{2}{*}{ Ln(Per Capita GDP) } & 1.393 & 0.872 & 1.126 & 0.911 \\
\hline & $(0.625)$ & $(0.570)$ & $(0.590)$ & (3.105) \\
\hline \multirow[t]{2}{*}{ Ln(Openness) } & -2.771 & -2.302 & -2.531 & 15.991 \\
\hline & $(0.689)$ & $(0.629)$ & $(0.650)$ & $(3.443)$ \\
\hline \multirow[t]{2}{*}{ Ln(Per Capita GDP)^Ln(Openness) } & 0.365 & 0.303 & 0.334 & -2.160 \\
\hline & $(0.095)$ & $(0.086)$ & $(0.089)$ & $(0.473)$ \\
\hline \multirow[t]{2}{*}{ Ln(Population Growth) } & 0.104 & 0.226 & 0.167 & 1.500 \\
\hline & $(0.504)$ & $(0.460)$ & $(0.476)$ & $(2.520)$ \\
\hline \multirow[t]{2}{*}{ Ln(Sec. Schooling Enrollment) } & -0.783 & -0.078 & -0.422 & -4.346 \\
\hline & $(0.407)$ & $(0.371)$ & $(0.384)$ & $(2.020)$ \\
\hline $\mathrm{N}$ & 415 & 415 & 415 & 417 \\
\hline
\end{tabular}

Notes: Coefficients significant at the $10 \%$ level or better are in bold. Per capita GDP is measured in 1985 dollars. Infant mortality is measured per 1,000 births. Measures for per capita GDP, openness and secondary schooling are 5-year lagged values. All regressions include country and year-fixed effects. Standard errors are in parentheses. 
Table 4: Openness, Water Resources Aid and Health Outcomes

Fixed Effects Models

\begin{tabular}{|c|c|c|c|c|c|c|c|c|}
\hline \multirow[b]{3}{*}{ Explanatory Variable } & \multicolumn{7}{|c|}{ Dependent Variable } & \\
\hline & \multicolumn{2}{|c|}{ Life Exp (Female) } & \multicolumn{2}{|c|}{ Life Exp (Male) } & \multicolumn{2}{|c|}{ Life Expectancy (Total) } & \multicolumn{2}{|c|}{ Infant Mortality } \\
\hline & $(1)$ & & $(2)$ & & (3) & & (4) & \\
\hline Ln(Per Capita GDP) & $\begin{array}{c}16.626 \\
(6.249)\end{array}$ & $\begin{array}{c}15.643 \\
(6.178)\end{array}$ & $\begin{array}{l}11.888 \\
(5.328)\end{array}$ & $\begin{array}{r}10.976 \\
(5.244)\end{array}$ & $\begin{array}{r}14.199 \\
(5.751)\end{array}$ & $\begin{array}{c}13.253 \\
(5.673)\end{array}$ & $\begin{array}{l}-69.551 \\
(24.967)\end{array}$ & $\begin{array}{l}-65.772 \\
(24.534)\end{array}$ \\
\hline Ln(Openness) & $\begin{array}{c}21.697 \\
(10.243)\end{array}$ & $\begin{array}{c}20.557 \\
(10.106)\end{array}$ & $\begin{array}{l}15.282 \\
(8.733)\end{array}$ & $\begin{array}{r}14.224 \\
(8.578)\end{array}$ & $\begin{array}{c}18.411 \\
(9.426)\end{array}$ & $\begin{array}{c}17.313 \\
(9.279)\end{array}$ & $\begin{array}{r}-100.042 \\
(40.877)\end{array}$ & $\begin{array}{l}-95.852 \\
(40.099)\end{array}$ \\
\hline Ln(Per Capita GDP)* Ln(Openness) & $\begin{array}{l}-2.975 \\
(1.487)\end{array}$ & $\begin{array}{l}\mathbf{- 2 . 8 2 6} \\
(1.467)\end{array}$ & $\begin{array}{l}-2.056 \\
(1.268)\end{array}$ & $\begin{array}{c}-1.918 \\
(1.245)\end{array}$ & $\begin{array}{c}-2.504 \\
(1.369)\end{array}$ & $\begin{array}{l}-2.361 \\
(1.347)\end{array}$ & $\begin{array}{l}13.626 \\
(5.931)\end{array}$ & $\begin{array}{l}13.087 \\
(5.816)\end{array}$ \\
\hline Ln(Population Growth) & $\begin{array}{c}1.321 \\
(1.002)\end{array}$ & $\begin{array}{c}1.263 \\
(0.987)\end{array}$ & $\begin{array}{c}1.101 \\
(0.854)\end{array}$ & $\begin{array}{c}1.048 \\
(0.837)\end{array}$ & $\begin{array}{c}1.209 \\
(0.922)\end{array}$ & $\begin{array}{c}1.153 \\
(0.906)\end{array}$ & $\begin{array}{c}-7.364 \\
(3.948)\end{array}$ & $\begin{array}{l}-7.124 \\
(3.869)\end{array}$ \\
\hline Ln(Sec. Schooling Enrollment) & $\begin{array}{l}-1.989 \\
(1.280)\end{array}$ & $\begin{array}{l}-2.143 \\
(1.263)\end{array}$ & $\begin{array}{c}-1.258 \\
(1.091)\end{array}$ & $\begin{array}{c}-1.401 \\
(1.072)\end{array}$ & $\begin{array}{l}-1.615 \\
(1.178)\end{array}$ & $\begin{array}{l}-1.763 \\
(1.160)\end{array}$ & $\begin{array}{c}8.983 \\
(5.056)\end{array}$ & $\begin{array}{c}9.609 \\
(4.963)\end{array}$ \\
\hline Ln(Per Capita Water Aid) & $\ldots$ & $\begin{array}{c}\mathbf{0 . 2 7 6} \\
(0.156)\end{array}$ & $\ldots$ & $\begin{array}{c}\mathbf{0 . 2 5 6} \\
(0.133)\end{array}$ & $\ldots$ & $\begin{array}{c}\mathbf{0 . 2 6 6} \\
(0.143)\end{array}$ & $\ldots$ & $\begin{array}{l}-1.193 \\
(0.613)\end{array}$ \\
\hline $\mathrm{N}$ & 146 & 146 & 146 & 146 & 146 & 146 & 145 & 145 \\
\hline
\end{tabular}

Notes: Coefficients significant at the $10 \%$ level or better are in bold. Openness is defined as [(imports+exports)/GDP] ${ }^{*} 100$ Per capita GDP is measured in 1985 dollars. Per capita aid is measured in 1999 dollars. Infant mortality is measured per 1,000 births. Measures for per capita GDP, openness and secondary schooling are 5-year lagged values. All regressions include country and year-fixed effects. Standard errors are in parentheses. 
Table 5: Openness and Foreign Aid

Fixed Effects Models

Dependent Variable is Log Per Capita Water Resources Aid

\begin{tabular}{|c|c|c|c|c|}
\hline \multirow[b]{2}{*}{ Explanatory Variable } & \multicolumn{3}{|c|}{ Measure of Openness Used } & \multirow[b]{2}{*}{ Black Market Premium } \\
\hline & $(\operatorname{Imp}+\operatorname{Exp} / \mathrm{GDP}) * 100$ & $(\mathrm{Imp} / \mathrm{GDP}) * 100$ & $($ Exp/GDP)*100 & \\
\hline \multirow{2}{*}{ Ln(Per Capita GDP) } & -1.506 & -1.469 & -1.475 & -1.211 \\
\hline & $(0.733)$ & $(0.731)$ & $(0.737)$ & $(0.907)$ \\
\hline \multirow[t]{2}{*}{ Ln(Openness) } & 1.483 & 1.426 & 1.148 & -0.043 \\
\hline & $(0.596)$ & $(0.584)$ & $(0.521)$ & $(0.132)$ \\
\hline \multirow[t]{2}{*}{ Ln(Population Growth) } & 0.277 & 0.231 & 0.340 & 0.737 \\
\hline & $(0.665)$ & $(0.666)$ & $(0.669)$ & $(0.838)$ \\
\hline \multirow[t]{2}{*}{ Ln(Sec. Schooling Enrollment) } & 0.722 & 0.714 & 0.703 & 0.736 \\
\hline & $(0.611)$ & $(0.612)$ & $(0.614)$ & $(0.757)$ \\
\hline $\mathrm{N}$ & 214 & 214 & 214 & 161 \\
\hline
\end{tabular}

Notes: Coefficients significant at the $10 \%$ level or better are in bold. Per capita GDP is measured in 1985 dollars. Per capita water resources aid is measured in 1999 dollars. Infant mortality is measured per 1,000 births. Measures for per capita GDP, openness and secondary schooling are 5-year lagged values. All regressions include country and year fixed-effects. Standard errors are in parentheses. 